\title{
EFFECT OF CHROMATE CONVERSION COATINGS ON THE ADHESION AND CORROSION RESISTANCE OF PAINTED 5083 ALUMINUM ALLOY
}

\author{
AMENEH ESHAGHI ${ }^{1}$, AKBAR ESHAGHI ${ }^{1,2}$ \\ ${ }^{1}$ Sari Branch, Islamic Azad University, Sari, Iran; \\ ${ }^{2}$ Maleke Ashtar University of Technology, Shahinshahr, Isfahan, Iran
}

The 5083 aluminum alloy surfaces were coated with chromate conversion coatings. Then epoxy paints were applied on the chromate and non-chromate treatment surfaces. The adhesion, hardness and corrosion resistance of the coated samples were evaluated using adhesion tape test, pencil hardness test, salt spray and electrochemical technique. The results indicated that the adhesion of the coating systems including chromate treatments was better than that of non-chromate conversion coatings, whereas the hardness of the coating systems was equal. Salt spray results showed that corrosion propagation from the scratched area in the painted samples with chromate treatment was lower than that of nonchromate coated surfaces. In addition, electrochemical corrosion measurements indicated that the coating system including chromate treatment presented lower corrosion current density, bigger polarization resistance and less negative corrosion potential than those of the non-chromate conversion coated surfaces.

Keywords: adhesion, aluminum, chromating, corrosion, paint.

Aluminum-magnesium alloys of the $5 \mathrm{xxx}$ series are commonly used in marine applications where low density, favorable mechanical properties and relatively good corrosion resistance are desired [1,2]. The electrochemical behavior of Al and its alloys has attracted the attention of many investigators. However, the natural oxide film on aluminum alloys does not offer sufficient protection against aggressive anions in seawater environment such as chloride ions leading to the formation of localized corrosion on the aluminum surface $[2,3]$. The protection by organic coatings is the most dominant among the various surface-protection methods due to their performance, commercial feasibility, and simple application [4]. However, the formation of adhesive and lasting organic coatings on aluminum alloys depends on the surface pretreatment prior to painting. Chromate conversion coatings (CCCs) are highly effective methods of aluminum alloys surface pretreatment for service in corrosive environments $[5,6]$. In spite of the toxicity, CCCs provide further advantages such as low cost, good paint adhesion, and quick and easy application [7, 8]. Another important aspect of CCCs is the dynamic repair of defects on coated metals, which is called self-healing effect. Self-healing arises with a storage of soluble $\mathrm{Cr}(\mathrm{VI})$ species located in the outer layer of mainly $\mathrm{Cr}$ (III) hydrated oxide/hydroxide coating. Upon contact with an electrolyte, the labile $\mathrm{Cr}(\mathrm{VI})$ is released into solution and is transported to damage areas where it is reduced and precipitated to form an insoluble $\mathrm{Cr}$ (III) hydroxide barrier [9, 10]. However, the main attractions for chromate conversion coatings in industrial applications are paint adhesion improvement on Al alloys and self-healing effect in the scratched area exposed to corrosive environments. The effect of chromate conversion coating on the adhesion and corrosion resistance of 5083 aluminum alloy painted was investigated in the present work.

Corresponding author: A. ESHAGHI, e-mail: eshaghi.akbar@gmail.com 
Experimental. The 5083 aluminum alloy specimens $(20 \times 10 \mathrm{~cm})$ with composition $4 \ldots .4 .9 \% \mathrm{Mg}, 0.4 \ldots 1 \% \mathrm{Mn}, 0.05 \ldots 0.25 \% \mathrm{Cr}, 0.4 \% \mathrm{Si}, 0.4 \% \mathrm{Fe}, 0.1 \% \mathrm{Cu}, 0.25 \%$ $\mathrm{Zn}$, and $0.15 \% \mathrm{Ti}$ were used as the substrate material for the current study. The specimens were degreased by wiping with a paper towel wetted with acetone, rinsed in deionized water, alkaline pickled $30 \mathrm{~s}$ in $\mathrm{NaOH}(12.5 \mathrm{~N})$ at $70^{\circ} \mathrm{C}$, rinsed, acid pickled $60 \mathrm{~s}$ in $50 \% \mathrm{HNO}_{3}$ at $30^{\circ} \mathrm{C}$, rinsed, dried and stored in an inert grease-free atmosphere for at least $24 \mathrm{~h}$. Some of these specimens were chromate conversion coated and others were the non-chromate coated.

For the chromate treatment, the specimen was immersed in the chromate bathe: $64 \mathrm{~g} / 1 \mathrm{H}_{3} \mathrm{PO}_{4}, 10 \mathrm{~g} / \mathrm{l} \mathrm{CrO}{ }_{3}, 5 \mathrm{~g} / \mathrm{l} \mathrm{NaF}, \mathrm{pH} 1.5, T=30^{\circ} \mathrm{C}$, for 2 min. After that, samples were rinsed with de-ionized water and dried at room temperature.

After proper surface preparation, epoxy paints (epoxy primer HB, MIL-P-24441/1, thickness $50 \mu \mathrm{m}$ and epoxy finish HB, MIL-P-24441/2, thickness $153 \mu \mathrm{m}$ ) were deposited on the chromate (thickness $2 \mu \mathrm{m}$ ) and non-chromate treatment samples by a brush method.

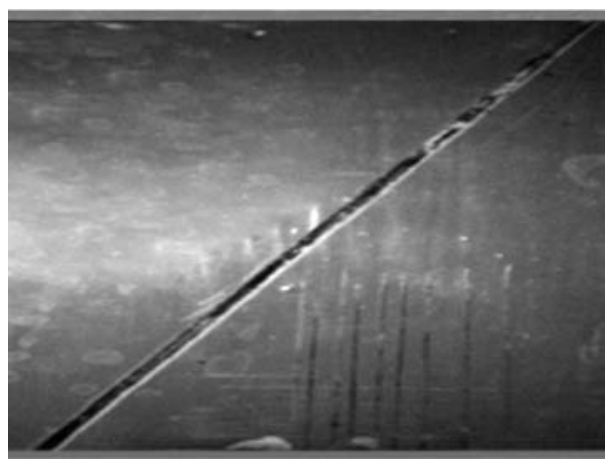

Fig. 1. Scratched sample in salt spray chamber.

The adhesion of coating systems (before and after of salt spray test) was measured according to the ASTM D3359 standard (Tape test). Hardness of coatings was measured according to the ASTM D3363 by using a pencil design (from 6B to $6 \mathrm{H})$. This method is one of the simplest to measure the coatings hardness.

The salt spray test was conducted on the coated specimens according to the ASTM B117 standard. For this test, the coated specimens were scratched diagonally (Fig. 1) and exposed in the salt spray fog chamber containing 5 wt.\% sodium

chloride solution at $35^{\circ} \mathrm{C}$ for a period of 30 days. Five percent sodium chloride solution was sprayed using a compressor with a pressure of $10 \ldots 25$ Psi. The observation of the coated specimens was taken periodically. The purpose of this test was the corrosion propagation measurement and the determination of coating blistering around the scratched area on the painted samples.

Electrochemical corrosion measurements were carried out in a $3.5 \mathrm{wt} \%$ sodium chloride aqueous solution. A conventional three-electrode electrochemical cell was utilized. In this cell, a SCE as the reference electrode, a platinum foil as the counter electrode, and the 5083 aluminum alloy coated and non-coated surfaces (non-scratched) were the working electrodes with the exposed area $1.0 \mathrm{~cm}^{2}$. The electrolyte solution was not stirred or aerated. Tafel plots were generated by scanning the potential from $E_{\text {corr }}$ to $\pm 250 \mathrm{mV}$. The scans were started at $250 \mathrm{mV}$ vs SCE with a sweep rate of $5 \mathrm{mV} / \mathrm{s}$. Corrosion current $\left(I_{\text {corr }}\right)$ was determined by superimposing a straight line along the linear portion of cathodic or anodic curve and extrapolation it through $E_{\text {corr }}$.

Results and discussion. Table 1 presents the results of adhesion tape test. By comparing the results, it can be seen that adhesion of the paint of the chromating surfaces is better than that of the non-chromating. Thus, the role of the surface pretreatment in the adhesion of coating on the aluminum alloy is determined. Aluminum has a flat surface, thus it cannot adsorb and keep the paints. Application of the chromate conversion coatings generate in the aluminum surfaces some micro voids which act as capillary tubes and paint penetrates into these voids and traps. Therefore, chromate conversion coating has capillaries and micro cavities, which provide mechanical interlocking. As a result, adhesion mechanism of paints in the presence of chromate conversion coating could be explained by the mechanical locking phenomena. 
Table 1. Adhesion and hardness results of coating systems

\begin{tabular}{|c|c|c|c|c|}
\hline Coating system & $\begin{array}{c}\text { Total thickness, } \\
\mu \mathrm{m}\end{array}$ & $\begin{array}{c}\text { Adhesion } \\
\text { (before salt spray) }\end{array}$ & $\begin{array}{c}\text { Adhesion } \\
\text { (after salt spray) }\end{array}$ & Hardness \\
\hline $\begin{array}{c}\text { 1-Chromate layer } \\
\text { Epoxy primer } \\
\text { Epoxy finish }\end{array}$ & 202 & $5 \mathrm{~B}$ & $5 \mathrm{~B}$ & $\mathrm{HB}$ \\
\hline $\begin{array}{c}\text { 2-Epoxy primer } \\
\text { Epoxy finish }\end{array}$ & 200 & $3 \mathrm{~B}$ & $0 \mathrm{~B}$ & $\mathrm{HB}$ \\
\hline
\end{tabular}

The hardness of coating depends on the topcoat resin kinds. In two coating systems, topcoats were equal and therefore, two coating systems showed equal hardness. The hardness of coatings does not depend on the surface pretreatment prior to painting.

The results of the salt spray test are shown in the Table 2 . The most effective properties of organic coating systems were the resistance to penetration of corrosive agents and corrosion propagation.

Table 2. Results of salt spray test

\begin{tabular}{|c|c|c|c|c|c|c|}
\hline \multirow{2}{*}{ Coating system } & \multicolumn{7}{|c|}{ Exposure time, $\mathrm{h}$} \\
\cline { 2 - 7 } & 120 & 240 & 360 & 480 & 600 & 720 \\
\cline { 2 - 7 } & \multicolumn{7}{|c|}{ Corrosion propagation, $\mathrm{mm}$} \\
\hline 1 & 0 & 0.03 & 0.07 & 0.12 & 0.16 & 0.2 \\
\hline 2 & 0.15 & 0.33 & 0.68 & 0.97 & 1.27 & 1.5 \\
\hline
\end{tabular}

According to salt spray results (Fig. 2$)$ corrosion propagation $\left(l_{\text {corr }}\right)$ from the scratched area into the coating systems including chromate treatment was lower than that of the non-chromate coating. The reason of this phenomenon can be attributed to the self-healing effect of chromate treatment. The hexavalent $\mathrm{Cr}$ particles in the chromate coatings dissolved due to arriving of moisture and these particles migrated to the scratched area and repaired the injury $[9,10]$. Then corrosion propagation reduces or stops. Furthermore, in the nonchromate treatment the blistering was seen around the scratched area, which is 5 $\mathrm{mm}$ in the diameter. This phenomenon occurs due to weak adhesion of coating and moisture, which easily penetrates under the coating and causes blistering. Thus, chromating treatments have several objectives for the painted surfaces: (1) to

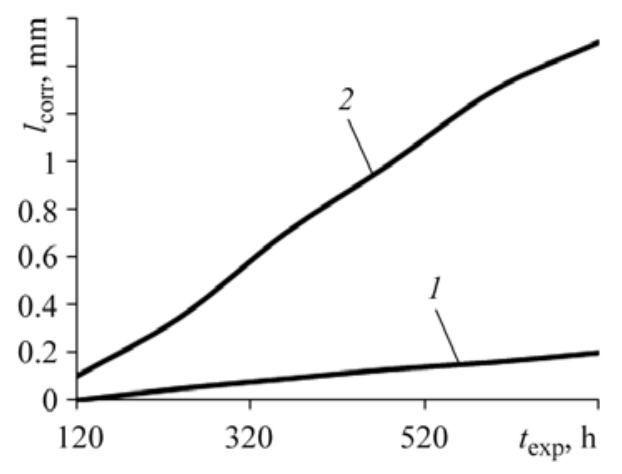

Fig. 2. Time dependence of corrosion propagation from the scratch on the specimen with chromate (1) and non-chromate (2) coating. act as a barrier layer providing corrosion protection, and (2) to improve the adhesion between the organic coating and the metal surface so that it avoids undercoat corrosion when it is applied before the organic coating and (3) a self-healing effect.

Table 3 presents the results of electrochemical corrosion measurement. Application of coatings on the 5083 aluminium alloy decreases the $I_{\text {corr }}$ value. The polarization resistance shows maximum for the coatings including chromate treatment and declines for the non-coated surfaces. These results indicate that the coatings including chromate layer protect aluminium better than the non-chromate layer. 
Table 3. Results of potentiodynamic polarization measurements

\begin{tabular}{|c|c|c|c|c|c|}
\hline Sample & Coating system & $E_{\text {corr }}, \mathrm{mV}$ & $I_{\text {corr }}, \mu \mathrm{A} / \mathrm{cm}^{2}$ & $R_{p}, \Omega$ & Corrosion rate, mpy \\
\hline $5083 \mathrm{Al}$ & - & -824 & 8.495 & 4.9 & 3.7 \\
\hline $5083 \mathrm{Al}$ & 1 & -758 & 1.849 & 62.2 & 0.81 \\
\hline $5083 \mathrm{Al}$ & 2 & -760 & 5.123 & 16.25 & 2.23 \\
\hline
\end{tabular}

\section{CONCLUSION}

The effect of chromate treatment on the adhesion and corrosion resistance of aluminium alloy painted was investigated. Adhesion test results indicated that paint adhesion on the aluminium alloy was improved by chromating treatment. Salt spray test showed that the samples with chromate treatment were more resistance to corrosion in the painted surface, which is congruent to the electrochemical evaluation.

РЕЗЮМЕ. Досліджено вплив хроматної конверсійної обробки алюмінієвого сплаву 5083 на адгезію епоксидних лакофарбових покривів та їх захисні властивості. Встановлено, що адгезія покривів по поверхні сплаву з хроматним конверсійним шаром більша, ніж за безхроматної обробки, а їх твердість в обох випадках однакова. Корозія металу під плівкою біля дефекту лакофарбового покриву за умов попереднього хроматування протікає не так інтенсивно, як після безхроматної обробки. Зразки сплаву зі системою покриву, яка охоплювала хроматну обробку, мали нижчі густини струму корозії, більший поляризаційний опір та менш негативний потенціал корозії, ніж безхроматно оброблені.

РЕЗЮМЕ. Исследовано влияние хроматной конверсионной обработки алюминиевого сплава 5083 на адгезию эпоксидных лакокрасочных покрытий и их защитные свойства. Установлено, что адгезия покрытий по поверхности сплава с хроматным конверсионным слоем больше, нежели после безхроматной обработки, а их твердость в обеих случаях одинакова. Коррозия металла под пленкой возле дефекта лакокрасочного покрытия после предварительного хромирования протекает не так интенсивно, как после безхроматной обработки. Образцы сплава с системой покрытия, которая охватывала хроматную обработку, имели меньшую плотность тока коррозии, большее поляризационное сопротивление и менее негативный потенциал коррозии, нежели безхроматно обработанные.

1. Annealing behavior of a modified 5083 aluminum alloy / S. Lin, Z. Nie, H. Huang, and B. Li // Mater. and Design. - 2010. - 31. - P. 1607-1612.

2. Mishra A. K. and Balasubramaniam R. Corrosion inhibition of aluminum alloy AA 2014 by rare earth chlorides / Corr. Sci. - 2007. - 49. - P. 1027-1044.

3. Ezuber H., Houd A. E., and El-Shawesh F. A study on the corrosion behavior of aluminum alloys in seawater / Mater. and Design. - 2008. - 29. - P. 801-805.

4. Kumar S. A., Alagar M., and Mohan V. Studies on corrosion-resistant behavior of siliconized epoxy interpenetrating coatings over mild steel surface by electrochemical methods / J. of Mater. Engng. and Performance. - 2002. - 11. - P. 123-126.

5. Substitution of hexavalent chromate conversion treatment with a plasma electrolytic oxidation process to improve the corrosion properties of ion vapour deposited AlMg coatings / N. M. Alanazi, A. Leyland, A. L. Yerokhin, and A. Matthews // Surface \& Coating Technol. - 2010. (In press)

6. Oki M. and Charles E. Chromate conversion coating on Al-0.2wt.\% Fe alloy / Materials Letters. - 2009. - 63. - P. 1990-1994.

7. Lu G., Ada E. T., and Zangari G. Investigation of the effect of chromate conversion coatings on the corrosion resistance of Ni based alloys / Electrochimistry Acta. - 2004. - 49. - P. 1461-1473.

8. Application of a factorial design to study a chromate-conversion process / S. Wery, M. D. P. Wery, M. Feki, and H. F. Ayedi / J. of Coating Technol. and Research. - 2010. - 7. - P. 39-47.

9. Andreva D. V. and Shchukin D. G. Smart self-repairing protective coating / Mater. Today. - 2008. - 11. - P. 24-30.

10. Synthesis and characterization of chromate conversion coatings on galvalume and galvanized steel substrates / M. A. D. N. Crespo, E. O. Bustamante, A. M. T. Huerta et al. // Metall. and Mater. Trans. A. - 2009. - 40. - P. 1631-1644. 